\title{
Lecturer Job Performance Study: Motivation, Emotional Intelligence, Organizational Culture and Transformational Leadership as Antecedents with Job Satisfaction as an Intervening
}

\author{
Mahfuzil Anwar ${ }^{1),}$ Grahita Chandrarin ${ }^{2)}$, Junianto Tjahjo Darsono ${ }^{3)}$, \\ Harianto Respati ${ }^{4)}$ \\ ${ }^{1}$ Doctoral Student in Economics Program, University of Merdeka Malang, Indonesia \\ ${ }^{2,3,4}$ Lecturers of the Economic and Business Faculty, University of Merdeka Malang, Indonesia
}

\begin{abstract}
This study describes the perception of private college lecturers in Banjarmasin, Indonesia. The purpose of this study is to test the lecturer job satisfaction on their performance achievement by considering aspects of motivation, lecturer emotional intelligence, organization culture and implementation of transformational leadership. Lecturers are respondents of this study. There are 187 samples from 352 study population. It is a quantitative research design with survey method. Data were analyzed using structural equation modeling. This study found that there is an effect of lecturer motivation, lecturer emotional intelligence, organizational culture and transformational leadership on job satisfaction. The second finding shows that there is an effect of lecturer motivation, lecturer emotional intelligence, organizational culture and transformational leadership on individual job performance. The third finding proved that lecturer job satisfaction has a positive impact on individual job performance. An important finding of this study is lecturer job satisfaction, which is retention of becoming an educator, is an engine for motivational aspects of fulfilling social needs, lecturer emotional intelligence, culture of establishing working groups and a transformational leadership style to improve the lecturer job performance.
\end{abstract}

Keywords: motivation, emotional intelligence, organizational culture, transformational leadership, job satisfaction, lecturer job performance

\section{Introduction}

This study started from researchers' curiosity about the lecturer job performance at private universities in Banjarmasin, South Kalimantan in Indonesia. In addition, researchers wanted to confirm previous research results which were relevant to some symptoms measured in this study. The education globalization phenomenon gives an impact on the implementation of Law No. 20 of 2003 about the national education system aimed at improving the education quality. Lecturers and teachers are required to improve their job performance in accordance with the criteria set by the government of Indonesia. Lecturers are a valuable asset for a college and as a driving force of learning process as well as key elements in determining the success of higher education. Therefore, lecturers must get a protected profession, obtain a reasonable reward, gain a sense of security in performing tasks, obtain a conducive working environment, gain clarity in their career, have a harmony relationship among fellow lecturers and an opportunity to develop themselves (Law No. 14, 2005). Table 1 shows the profile of lecturers in Banjarmasin, South Kalimantan Province.

The government imposes the same lecturer performance achievement, either to the public or private lecturers. Private colleges are more autonomous than public colleges, of course, lecturers who work in private colleges have different degrees of satisfaction from public lecturers. Related to this fact, the measurement and investigation of lecturer job satisfaction and job performance at private colleges become an interesting phenomenon rather than public colleges. So the focus of this study is lecturers who work in private colleges in Banjarmasin. Studies on job satisfaction and job performance have been done by previous researchers. Supriyanto et al. (2012) who examined the job satisfaction of bank managers in Indonesia proved there is job satisfaction influence on the job performance of individual bank manager. Rinawati (2013) did study on insurance business also proved that there is influence between job satisfaction and employee job performance. Suryana et al. (2010) who tested employee job satisfaction and job performance in the mining company showed significant results. Brahmasari (2008) who tested at manufacturing companies showed that job satisfaction affects the employee job performance. Studies on job satisfaction and individual job performance have been carried out in some services or manufacturing industry and both showed concrete results that there are effects. This study attempted to examine lecturer job satisfaction and job performance at private colleges, especially in Banjarmasin which has unique characteristics. Some determinants of lecturer job satisfaction in the private 
college can be caused by the aspect of individual motivation, emotional intelligence, culture and leadership. It was felt by the majority of private lecturers, whose colleges are operating independently, have a strong economic pressure due to the lack of government assistance. Having existing facilities and potential makes private colleges are competing to each other in order to obtain the number of new students. Therefore, it takes some potential, such as individual motivation, emotional intelligence, organizational culture and transformational leadership to maintain the existence of private colleges. A previous study conducted by Nuraningsih et al. (2015) in the service industry proved there is influence between emotional intelligence and employee job satisfaction. Supriyanto et al. (2012) examined the effect of transformational leadership and job satisfaction with the result that transformational leadership can improve job satisfaction of manager banks. Study in the wood processing industry by Koesmono (2005) found that organizational culture can boost employee job satisfaction. Porter (1983) explained that the determinant of individual job satisfaction is the motivation. Study results and experts' views motivate researchers to investigate back on the impact of lecturer motivational, lecturer emotional intelligence, organizational cultural aspects of private colleges and the type of transformational leadership on the lecturer job satisfaction.

Table 1. Number of Lecturers at Private Colleges in Banjarmasin

\begin{tabular}{|c|c|c|c|c|c|c|c|c|c|c|}
\hline \multirow[t]{2}{*}{ No. } & \multirow[t]{2}{*}{ PRIVATE COLLEGES } & \multicolumn{3}{|c|}{$\begin{array}{l}\text { CIVIL SERVANT } \\
\text { LECTURER } \\
\text { (people) }\end{array}$} & \multirow[t]{2}{*}{$\begin{array}{l}\text { Number } \\
\text { (people) }\end{array}$} & \multicolumn{3}{|c|}{$\begin{array}{c}\text { FOUNDATION } \\
\text { LECTURER } \\
\text { (people) }\end{array}$} & \multirow[t]{2}{*}{$\begin{array}{l}\text { Number } \\
\text { (people) }\end{array}$} & \multirow[t]{2}{*}{ Total (people) } \\
\hline & & $\mathrm{S} 1$ & $\mathrm{~S} 2$ & S3 & & S1 & $\mathrm{S} 2$ & S3 & & \\
\hline 1 & UVAYA & 1 & 18 & 1 & 20 & 29 & 75 & 2 & 106 & 126 \\
\hline 2 & UNISKA & 1 & 46 & 7 & 54 & 75 & 179 & 8 & 262 & 316 \\
\hline 3 & STIE Indonesia & 0 & 9 & 1 & 10 & 0 & 25 & 1 & 26 & 36 \\
\hline 4 & STIA Bina Banua & 0 & 4 & 1 & 5 & 9 & 10 & 8 & 27 & 32 \\
\hline 5 & STIMI Banjarmasin & 0 & 5 & 0 & 5 & 0 & 6 & 2 & 8 & 13 \\
\hline 6 & STIH Sultan Adam & 0 & 4 & 0 & 4 & 21 & 13 & 1 & 35 & 39 \\
\hline 7 & STIE Nasional & 0 & 7 & 2 & 9 & 0 & 18 & 0 & 18 & 27 \\
\hline 8 & STIKIP PGRI & 2 & 17 & 3 & 22 & 54 & 101 & 0 & 155 & 177 \\
\hline 9 & STIE Pancasetia & 1 & 6 & 0 & 7 & 14 & 74 & 4 & 92 & 99 \\
\hline 10 & STIKES Cahaya Bangsa & 0 & 3 & 0 & 3 & 10 & 11 & 0 & 21 & 24 \\
\hline 11 & STIKES Muhammadiyah & 2 & 6 & 0 & 8 & 8 & 3 & 1 & 12 & 20 \\
\hline 12 & STMIK Indonesia & 0 & 3 & 0 & 3 & 42 & 24 & 0 & 66 & 69 \\
\hline 13 & STIKES Suaka Insan & 4 & 2 & 0 & 6 & 16 & 14 & 0 & 30 & 36 \\
\hline 14 & STIKES Sari Mulia & 6 & 4 & 0 & 10 & 21 & 10 & 0 & 31 & 41 \\
\hline & Number & 17 & 134 & 15 & 166 & 299 & 563 & 27 & 889 & 1055 \\
\hline
\end{tabular}

Source: Directory of Kopertis Region XI Kalimantan, 2016

The link between motivation, organizational culture, leadership, individual job satisfaction and job performance have ever undertaken by Munir (2013) whose study at a Hospital showed that the employee job performance may be created by aspects of motivation, organizational culture, leadership and individual job satisfaction. Viewing and looking at the results of previous studies, researchers wanted to test whether it is true that lecturer job satisfaction as part of efforts to improved its lecturer job performance has a relation with antecedent aspects, such as individual motivation, organizational culture, transformational leadership and individual job satisfaction in private colleges in Banjarmasin, Indonesia. Therefore the purpose of this study is to examine job satisfaction mediates motivation, emotional intelligence, organizational culture and transformational leadership to improve the lecturer job performance. Based on the results of previous studies and to answer the purposes of this study, hypothesized;

H1: Motivation, emotional intelligence, organizational culture and transformational leadership have a significant effect on job satisfaction.

$\mathrm{H} 2$ : Motivation, emotional intelligence, organizational culture and transformational leadership have a significant effect on the lecturer job performance.

H3: There is a significant effect between job satisfaction and lecturer job performance.

\section{a. Individual Job Performance}

\section{Literature}

Wibowo (2007) described about job performance is doing the work and results of the work. Mangkunagara (2007) suggested the job performance is the result of the quality and quantity which achieved by an employee. Individual job performance is the result of work achieved by a lecturer in performing duties and works based on his/her responsibilities and authority as a lecturer. Bernadin et al. (1993) imposed a limit on the job performance as a record of outcomes produced on a specified job function or activity during, a specified time period. Chung et al. (1981) suggested the job performance assessment is a way of measuring the 
individual's contributions to the organization. Bernardin and Russel (1993) explained there are six criteria that can be used to measure job performance, such as:

1) Quality, is the degree to which the process or the results of carrying out an activity approaches perfection or fulfilling the activity's intended purpose.

2) Quantity, the amount produced, expressed in terms such as rupiah value, number of units, and number of completed activity cycles.

3) Timeliness, the degree to which an activity completed at a desired time by paying attention to coordination, as well as the time available for other activities.

4) Cost Effectiveness, the degree to which the use of organization's resources (human, financial, technological, material) is maximized in the sense of getting the highest gain or reduction in loss from each unit of a resource.

5) Need for supervision, the degree to which an employee can carry out a job function without either having to request supervisory assistance or requiring supervisor intervention to prevent an adverse outcome.

6) Interpersonal Impact is the degree to which employees have self-esteem, goodwill and cooperativeness among coworkers and subordinates.

\section{b. Job satisfaction}

Grenberg et al (1976) stated that job satisfaction is a set of favorable or unfavorable feeling with which employees view Reviews their works. Schemerhorn (1991) suggested that job satisfaction is the degree to which people feel positively or negatively about their job. It is emotional responses to one's tasks, as well as the physical and social condition of workplace. In concept, job satisfaction also indicates the degree to which the expectation in someone's psychological contract are fulfilled. In this concept, job satisfaction also indicates that there are degrees or levels of workers' expectations in the psychological form. Davis et al (1995) suggested that job satisfaction is part of life satisfaction, the nature of one's environment of the job influences one's feeling on the job. Similary, since a job is an important part of life, job satisfaction influences one's general life satisfaction. Similarly, since a job becomes an important part of life, job satisfaction becomes one of life satisfaction in general. This is seen in a positive attitude towards the employees' work in the workplace. As'ad, (2005) stated job satisfaction is a person's feelings toward work. Job satisfaction can also be said as a work reflection (job attitude) that is positive. Robbins et al (2008; 99) defined job satisfaction as a positive feeling about someone's work that is the result of a characteristic evaluation. Individual job satisfaction can be reflected by the attendance rates, enjoying the work, enjoying the environments, liking the superiors, participation rates and retention rates. The thing to note is a job requires interaction between coworkers, leaders, rules and organizational policies, job performance standards, living and working conditions. Job satisfaction can also be interpreted as an attitude that arises based on an assessment of the work situation. A satisfied employee prefers work situations rather than dislikes them.

\section{c. Motivation}

Robbins et al. (2008) defined motivation as a process that explains the intensity, direction and persistence of an individual in order to achieve the goal. Many people mistakenly perceive motivation as a personal characteristic that is owned by someone while others do not. One of the most famous motivation theories is Maslow's theory which hypothesizes there are five needs in each human being, such as: (1) physiological, includes the need to free from hunger, thirst, need a shelter, sex and other physical needs; (2) safety, includes protection from physical and emotional dangers; (3) social, includes affection, ownership, acceptance, and friendship; (4) self-esteem, includes internal achievement factors, such as self-respect, autonomy, and achievement. External achievement factors such as, status, recognition and attention; (5) selfactualization, such as an impulse to become a person according to his/her abilities, includes the growth, the achievement of one's potential, and self-fulfillment.

\section{d. Emotional Intelligence}

Emotional Intelligence is an emotional skill of controlling an individual's emotion through self control, working spirit and perseverance, empathy so that an individual can relate to others well. Salovey and Mayer (1990), stated that emotional intelligence consists of five bases, namely: (1) Self Awareness (identifying self emotion) is the ability to recognize and to understand your feelings. (2) Self-control (managing emotions) is the ability to manage emotion which is dealing with feelings so that they can be revealed appropriately (3) Self Motivation (self-motivated) is a person's ability to motivate himself which is the ability that develops based on self-control ability. (4) Empathy (recognizing emotions in others) is the ability to recognize or to understand the emotions of others. (5) Social Skills (relationship) is a person's ability to manage relationship with others. 


\section{e. Organizational culture}

Kilmann et al. (1988) suggested that the organization culture is the system of values, beliefs, assumptions, or norms that have long been in force, agreed upon and followed by the members of an organization as a code of conduct and solving problems organizational. Davis et al. (1995), states that organizational culture is a pattern of organizational beliefs and values that understood and practiced by the organization so that the pattern gives its own meaning and becomes basic rules of behavior in the organization. Wallach (1983) presented three dimensions of organizational, namely:

1) Supportive culture, demonstrates teamwork and work environment which oriented in people friendly, encouraging and reliable.

2) Innovative culture, refers to a creative work environment, result oriented and challenging;

3) Bureaucracy culture, is hierarchical and clustered;

\section{f. Transformational Leadership}

Bass et al. (1988: 20) states that the essence of transformational leadership is a leadership style which is characterized by behaviors that provide empowering and strengthening subordinates to achieve organizational goals. This leadership style is more likely to be superior performance in organizations that are facing demands for renewal and change. Bass et al (1988; 29), suggested a leader can transform subordinates in four ways, namely;

1) Charisma (Idealized Influence), a transformational leader looks charismatic by his followers and has a power and an influence. Charisma in general is related to the actions of followers as a reaction to the leader's behavior. A transformational leader evokes and encourage his followers with a vision of what can be accomplished via subordinate's extra effort (Personal Extra Effort).

2) Inspirational Motivation, the leader uses symbols and simple emotional appeals to raise awareness or understanding of desired objectives together and also motivate and inspire subordinates to communicate regarding the work challenges clearly.

3) Intellectual Stimulation, the leader encourages followers to rethink old ways of doing things or to change his past. Followers are encouraged to ask again about values and beliefs, and they are encouraged creatively to build themselves.

4) Individual Consideration, followers are required differently but in a balanced or one-to-one basis. Individual consideration indicates an attempt to not only pays attention to the leader and to meet the followers' needs, but it also increases the needs in an effort to maximize and to expand their potential. The leader can act as a trainer (coach) or advisor (mentor).

\section{a. The study design}

\section{Research Methods}

This study was a quantitative research and its aim was to test hypothesis. This study collected primary data. This study analyzed the large number of respondent's perceptions so that the survey method was used to collect data. There are six variables in this study consisting of four exogenous variables and two endogenous variables. Each variable is measured by several indicators. Analysis units of this study are professors who work in the private colleges. Structural equation modeling analysis was used to explain the hypothesis and the findings of this study.

\section{b. The study measurement}

This study used a questionnaire as a means of collecting primary data. Respondents answered several proposed statements. The Likert scale is used to answer every statement offered. The choice at number one shows a very disagree perception, second choice disagrees, number three is neutral, number four agrees and number five strongly agrees. Each instrument explains the research indicator. The average value of indicators represents the perceptions of some measuring instruments. 
Table 2. The Study Variables, Indicators and Notations

\begin{tabular}{|l|c|l|c|}
\hline \multicolumn{2}{|c|}{ Exogenous Variables } & Y1 & Job satisfaction \\
\hline X1 & Motivation & Y11 & Attendance rate \\
\hline X11 & Physiological Needs & Y12 & Enjoy the job \\
\hline X12 & Safety Needs & Y13 & Enjoy the environment \\
\hline X13 & Social Needs & Y14 & Like the superior \\
\hline X15 & Self-Esteem Needs & Y15 & Participation rate \\
\hline X2 & Emotional intelligence & Y16 & Retention rate \\
\hline X21 & Self Awareness & Y2 & Lecturer job performance \\
\hline X22 & Self control & Y21 & Quality \\
\hline X23 & Self Motivation & Y22 & Quantity \\
\hline X24 & Empathy & Y23 & Timeliness \\
\hline X25 & Social Skills & Y24 & Cost effectiveness \\
\hline X3 & Organizational culture & Y25 & Need for supervision \\
\hline X31 & Supportive & Y26 & Interpersonal Impact \\
\hline X32 & Innovative & & \\
\hline X33 & Bureaucracy & & \\
\hline X4 & Transformational leadership & & \\
\hline X41 & Charismatic & & \\
\hline X42 & Has Influence & & \\
\hline X43 & Have a clear vision & & \\
\hline X44 & Transformation of subordinate minds & & \\
\hline
\end{tabular}

Table 2 illustrates that each variable is reflected by several indicators that have been adapted to the theoretical reasoning and empirical study results and also they are relevant to the research phenomenon. The relationship among research variables can be explained by the structural equation model as in Figure 1.

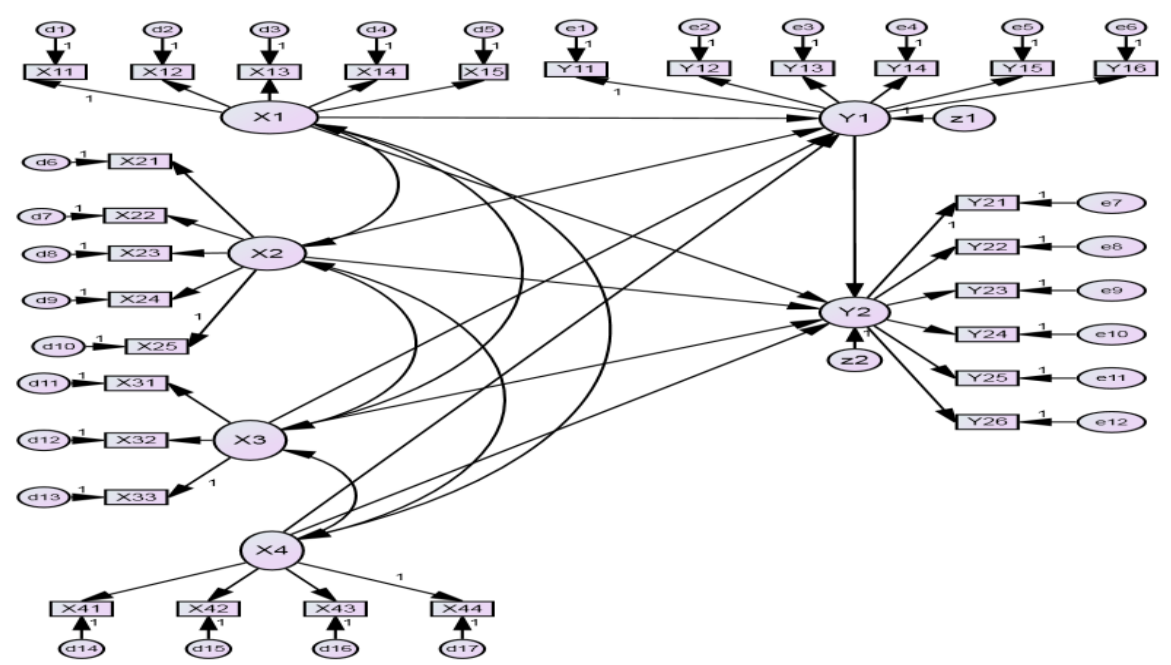

Figure 1. Structural Equation Modeling

\section{c. Population and sample}

The total population of this study are 1055 lecturers working in private and public colleges. The focus of this study are lecturers working in private colleges so it is found that the population access to the study are 899 lecturers. Respondent criteria surveyed, namely: 1) A lecturer who works at private colleges, 2) the working period are more than 5 years, 3) A lecturer who has a professional certificate as an educator, 4) The lecturer position is at the intermediate level and above (Level of Lektor in Indonesia term). From 899 population accesses, 352 respondents were found as a study population which meets the study criteria. The sample determination used the Slovin formula $\left(\mathrm{N} / 1+\mathrm{N \alpha}^{2}\right)$ is $352 / 1+352(0.05)^{2}$ is obtained 187 as samples of the study, questionnaires were returned as many as 130 samples to be analyzed in the study. A sampling technique used a probability approach which is a simple random sampling where every lecturer who works at private universities different has the same opportunities to be studied. There are no striking differences among lecturers who work in private colleges. 


\section{Research Results}

Questionnaires that respondents answered were collected and tabulated. All of the study instruments were tested their validity and reliability. The test results showed that all instruments are proven to be able to measure indicators of the study and they have a good level of consistency. The link between variables was tested on the analysis of structural equation modeling as presented in Appendix 1. The analysis result of structural equation modeling explains that Chi Square model 305.983 is less than Chi Square table at the error rate of 0.05 $(\mathrm{DF}=362)$ amounted to 407.366 . The model probability is very good because it exceeds 0.05 . RMSEA of 0.012 does not exceed the cut-off value (0.08). The size of TLI (0.974) strongly supports the model because it exceeds 0.95 . The results of all comparisons can be concluded that structural equation models have already met the criteria to be analyzed in this study. The results of the study indicator description and loading factor values are presented in Table 3. The analysis result of the observational data indicates the data distribution is normal. The analysis result of Mahalanobis distance shows that as many as 130 observation units are found no observational data on the outlier position. The analysis results of the product moment correlation shows the relationship among variables observed are found no multicollinearity symptoms.

Table 3. The Analysis Result of Exogenous Variables

\begin{tabular}{|c|c|c|c|c|}
\hline \multicolumn{2}{|r|}{ Exogenous variables } & Mean & Factor Loading & Cronbach's Alpha \\
\hline $\mathrm{X} 1$ & Motivation & & & 0.87 \\
\hline $\mathrm{X} 11$ & Physiological Needs & 3.92 & 0.68 & \\
\hline $\mathrm{X} 12$ & Safety Needs & 3.91 & 0.66 & \\
\hline $\mathrm{X} 13$ & Social Needs & 4.03 & 0.72 & \\
\hline $\mathrm{X} 14$ & Self-Esteem Needs & 4.08 & 0.73 & \\
\hline $\mathrm{X} 15$ & Self-Actualization Needs & 3.99 & 0.67 & \\
\hline $\mathrm{X} 2$ & Emotional intelligence & & & 0.92 \\
\hline $\mathrm{X} 21$ & Self Awareness & 4.12 & 0.82 & \\
\hline $\mathrm{X} 22$ & Self control & 4,23 & 0.91 & \\
\hline $\mathrm{X} 23$ & Self Motivation & 4.16 & 0.72 & \\
\hline $\mathrm{X} 24$ & Empathy & 4.17 & 0.82 & \\
\hline $\mathrm{X} 25$ & Social Skills & 3.95 & 0.72 & \\
\hline $\mathrm{X} 3$ & Organizational culture & & & 0.89 \\
\hline $\mathrm{X} 31$ & Supportive & 4.11 & 0.96 & \\
\hline X32 & Innovative & 3.93 & 0.86 & \\
\hline $\mathrm{X} 33$ & Bureaucracy & 3.82 & 0.86 & \\
\hline $\mathrm{X} 4$ & Transformational leadership & & & 0.92 \\
\hline $\mathrm{X} 41$ & Charismatic & 3.76 & 0.83 & \\
\hline $\mathrm{X} 42$ & Has Influence & 3.68 & 0.85 & \\
\hline $\mathrm{X} 43$ & Have a clear vision & 3.86 & 0.91 & \\
\hline $\mathrm{X} 44$ & Transformation of subordinate minds & 3.77 & 0.89 & \\
\hline
\end{tabular}

Table 3. describes the motivation which shows the highest loading factor value in the indicator group of the motivation variable by 0.73 is explained by the self-esteem which its mean value is 4.08 . The stronger emotional intelligence variable is explained by the self-control with the highest loading factor value of 0.91 in the indicator group of the emotional intelligence which its mean value is 4.23 . Supportive behavior is more able to explain about organizational culture than other indicators with loading factor value of 0.96 which its mean value is 4.11. Among the four tested indicators of transformational leadership, the item of has a clear vision with the loading factor value of 0.91 which its means of 3.86 is able to be superior to explain about transformational leadership.

Table 4. The Analysis Result of Endogenous Variables

\begin{tabular}{|c|c|c|c|c|}
\hline \multicolumn{2}{|c|}{ Endogenous variable } & Mean & Factor Loading & Chronbach's Alpha \\
\hline Y1 & Job satisfaction & & & 0.89 \\
\hline Y11 & Attendance rate & 3.77 & 0.68 & \\
\hline $\mathrm{Y} 12$ & Enjoy the job & 4.01 & 0.60 & \\
\hline Y13 & Enjoy the environment & 4.01 & 0.66 & \\
\hline Y14 & Like the superior & 3.75 & 0.55 & \\
\hline Y15 & Participation rate & 3.76 & 0.64 & \\
\hline Y16 & Retention rate & 4.04 & 0.70 & \\
\hline $\mathrm{Y} 2$ & Lecturer job performance & & & 0.84 \\
\hline Y21 & Quality & 3.86 & 0.58 & \\
\hline Y22 & Quantity & 3.83 & 0.64 & \\
\hline Y23 & Timeliness & 4.19 & 0.65 & \\
\hline $\mathrm{Y} 24$ & Cost effectiveness & 4.03 & 0.61 & \\
\hline Y25 & Need for supervision & 4.06 & 0.58 & \\
\hline Y26 & Interpersonal Impact & 4.22 & 0.68 & \\
\hline
\end{tabular}


Table 4. The analysis results of the job satisfaction variables explains that the retention rate is superior to explain the job satisfaction with the support of the highest loading factor value in the indicator group of job satisfaction variable by 0.70 which its mean value is (4.04). Lecturer job performance variable is strongly explained by the interpersonal impact with the highest loading factor value of 0.68 which its mean is 4.22 in the indicator group of lecturer jon performance variables. The result of interrelation testing between research variables is presented in Table 5.

Table 5. The Analysis Result of Influence between Study Variables

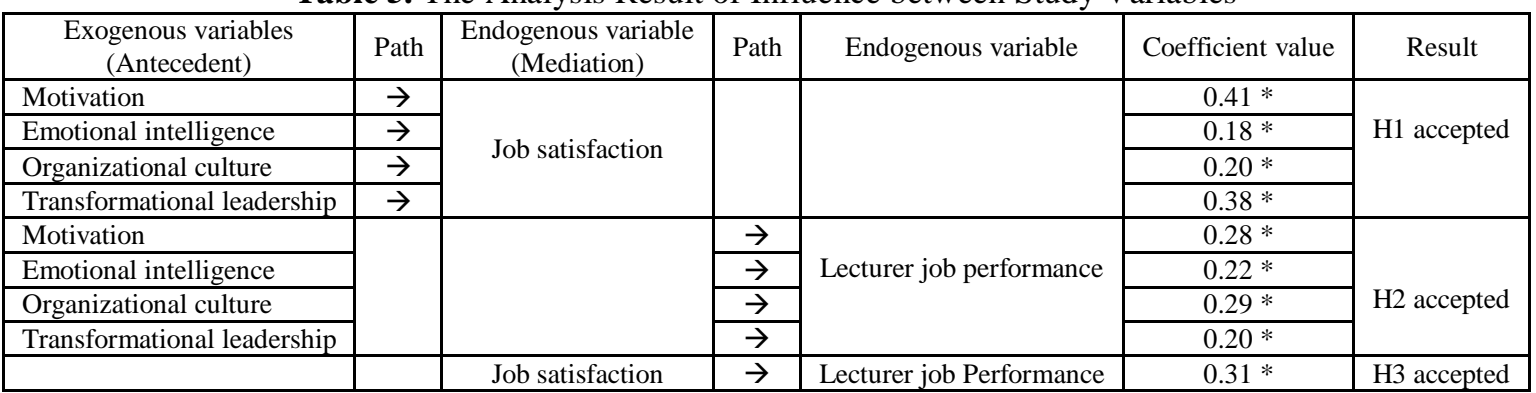

*) significance level of $\mathrm{p} \leq 0.05$

The coefficient value in Table 5 is obtained from the analysis result of structural equation modeling (appendix 1). The test result of motivation, emotional intelligence, organizational culture and transformational leadership shows there is a significant effect on the job satisfaction. The result of this test indicates that the first study hypothesis can be tested. The first hypothesis testing result obtains the finding that the motivation dominantly influences the job satisfaction. The test results of motivation, emotional intelligence, organizational culture and transformational leadership shows a significant effect on the lecturer job performance. The test result indicates the study hypothesis can be tested. The second hypothesis testing result obtains the finding that the organizational culture dominantly influences the lecture job performance. The test result of job satisfaction shows a significant effect on the lecturer job performance. The test result indicates the third research hypothesis can be tested.

\section{Discussion}

Motivation (Maslow) was a force generated from someone's desire to satisfy the needs, such as hunger and thirst, which are measured based on five hierarchy ie. physiological needs, safety needs, social needs, selfesteem needs and self-actualization needs. Motivation of private college lecturer in Banjarmasin can be characterized by the self-esteem needs. Robbins (2008) explained that motivation is a process which explains the intensity, direction, and persistence of an individual in an effort to achieve the goal. It shows that the intensity, direction and persistence of mostly private college lecturers in Banjarmasin are to meet the self-esteem needs in society. This is relevant to the respondent's characteristics with range of 51 to 55 years old which is greater than the other age range. Most of the respondents work more than 25 years, it suggests that the need for lecturer's status recognition is the primary requirement. Lecturer's emotional intelligence is the ability to recognize the feeling oneself, grab it and encourage it to help the mind, to understand the feeling and its meaning for the emotional and intellectual development. Emotional intelligence of private college lecturers in Banjarmasin is more visible by the ability to control themselves (self-control), especially on the sense of responsibility and accepting criticism. Age factor, work period and experience determine the lecturer's ability to do the self-control. Organizational culture is a pattern of organizational beliefs and values which are understood and practiced by individual in the organization (Davis, 1995). Organizational values which are understood and imbued become a differentiator between an organization on a lecturer group and other organizations. Cultural organization in group of private college lecturers in Banjarmasin is more visible in the supportive behavior, especially in setting up a working group. The lecturer's supportive behavior is implemented in three lecturer's main activities, such as a teaching, a research and a community service.

Transformational leadership is more likely to be on an effort to change the organization to be better through the knowledge transfer among lecturers. The model of transformational leadership style desired by private college lecturers in Banjarmasin is the transformational leadership is able to convey the organization's vision clearly. Under a transformational leadership which has a clear vision, it is very necessary to have lecturers developed their potential. This result appears in the percentage of lecturer growth in having further studies on the Strata two and three which is increasing every year. Job satisfaction is an emotional state that is enjoying the job. Job satisfaction of private college lecturers in Banjarmasin is shown by the high retention rate of work as a lecturer in the college. This result is supported by data of respondent characteristic whose working

DOI: $10.9790 / 487 X-1906020109 \quad$ www.iosrjournals.org $7 \mid$ Page


period is above 25 years, which indicates the lecturer feels satisfied to work at the institution until the end of the term as lecturer. Job performance is the work result which has a strong relationship to organization's strategic goals. Job performance is the work result which achieved by an individual who are adapted to the role or task within a certain period (Gomes, 1995). The job performance of private college lecturer in Banjarmasin is more visible on the interpersonal impact which is having a good relationship among fellow lecturers, such as maintaining each other's lecturer pride, maintaining the good name of the organization where they work, and having a good cooperation. This study is to test perception of private college lecturers in Banjarmasin. This study found the lecturer motivation to meet recognition needs can improve the lecturer job satisfaction. The link between motivation and job satisfaction of an individual has ever been studied by Munir (2013) who studied it at the hospital and found that employee job satisfaction can be created by motivation aspects.

Emotional intelligence to control oneself, especially controlling the sense of responsibility and willing to accept criticism from others, can realize the lecturer job satisfaction. The study result supports the previous study which conducted by Nuraningsih et al. (2015) in the service industry to prove that there is an influence between emotional intelligence and employee job satisfaction. Organizational culture in the group of private college lecturers in Banjarmasin is more visible in the supportive, especially when setting up a working group, it creates its own sense of satisfaction as professional educators. This result supported the study by Koesmono (2005) in the wood processing industry; it was found that organizational culture can boost employee job satisfaction. The model of transformational leadership style which is able to convey the organization's vision clearly is able to create a sense of satisfaction for lecturers in order to increase their potential. It is similar to the study of Supriyanto at al. (2012) who examined the effect of transformational leadership on job satisfaction with the result that transformational leadership can improve job satisfaction of bank managers. It means that the banking industry and education have a thing in common; they want to have the transformational leadership style. This study also found the lecturer motivation in meeting the recognition needs, the emotional intelligence of self-control in developing a sense of responsibility, the organizational culture which is more focused on aspects of the working group formation, and the transformational leadership style which is able to explain the vision clearly are proven to be able to improve the lecturer job performance. It can be seen in the work patterns of the lecturers who prefer to work together in groups in order to mutually maintain the institution's good name. The result of this study is not different with Munir's study (2013), which studied that the job performance of hospital employees can be created by the aspect of motivation, organizational culture, and leadership. This study also describes the relationship between job satisfaction and performance. The test result found that job satisfaction on a high retention rate as a lecturer at the college is able to improve the job performance of private college lecturers in Banjarmasin.

\section{Conclusions And Recommendations}

An important finding in this study is job satisfaction of lecturers who work in the private colleges in Banjarmasin can be seen in their retention rate of becoming educators. Lecturer job satisfaction is affected by several conditions, such as the motivation in meeting the recognition needs, the emotional intelligence on aspects of responsibility, the cultural behavior in setting up the working group, and the transformational leadership style that is able to explain the organization's vision clearly. The higher retention rate to become a lecturer, the higher lecturer job performance may increase. It can be concluded that the retention rate as an educator in the college is an important key for a lecturer to improve the job performance. Therefore, in the future research, it is suggested to reinvestigate the aspect of individual retention in an organization and the job satisfaction on a more extensive research scale.

\section{References}

[1] As'ad, Moh, 2005, Psikologi Industri; Seri Ilmu Sumberdaya Manusia, Liberty, Yogyakarta.

[2] Bass, Bernard M and Avolio, Bruce J, 1988, Transformational Ledership Development Manual for the Multifactor Leadership Quentionnaire Palo Alto California; Consulting Psychologists Press, Inc.

[3] Bernardin H. John and Russel, Joyce, 1993, Human Resources Management, An Expremental Approach, McGraw-Hill Book Company.

[4] Brahmasari, Ida, Ayu and Agus Suprayitno, 2008, Pengaruh Motivasi kerja, Kepemimpinan dan Budaya Organisasi Terhadap Kepuasan Kerja Karyawan serta dampaknya pada Kinerja Perusahaan" (Studi kasus pada PT. Pei Hai Internasional Wiratama Indonesia). Jurnal Manajemen dan Kewirausahaan Vol.10 No.2 pp 124-135.

[5] Chung, Kae H, and Leon C. Megginson, 1981, Organizational Behavior, Developing Managerial Skills, Harper \& Row, Publishers, New York.

[6] Davis and Newston, 1995, Managing Corporate Culture, Cambridge.

[7] Direktori Kopertis Wilayah XI Kalimantan, 2016 tentang Daftar Perguruan Tinggi Kopertis XI Wilayah Kalimantan.

[8] Denison, D.R, 1990, Corporate Culture and Organizational Effectiveness, John Willey \& Sons, New York.

[9] Grenberg, J and R.A. Baron, 1976, Behavior in Organization, Prentice Hall, Englewood Clifts, NJ.

[10] Kilmann, and Ralph H, Saxton, Mary J, Serpa, Roy, 1988, Gaining Control of The Corporate Culture, San Fransisco,Jossey-Bass Publishers.

[11] Koesmono, 2005, Pengaruh Budaya Organisasi terhadap Motivasi dan Kepuasan Kerja serta Kinerja Karyawn Pada Sub Sektor Industri Pengolahan Kayu Skala Menengah di Jawa Timur. Jurnal Manajemen \& Kewirausahaan. Vol.7 No.2 
[12] Mangkunegara, Anwar Prabu, 2007, Manajemen Sumber Daya Manusia Perusahaan, PT. Remaja Rosdakarya, Bandung.

[13] Munir, Misbachul, 2013, Pengaruh Motivasi Kerja, Kepuasan Kerja, Budaya Organisasi dan Kepemimpinan Terhadap Kinerja Karyawan Rumah Sakit Umum Daerah Tugurejo Semarang Jurnal FE Universitas Dian Nuswantoro Semarang.

[14] Nuraningsih and Ni Luh Putu, Made Surya Putra, 2015, Pengaruh Kecerdasan Emosional terhadap Kepuasan Kerja dan Stres Kerja pada The Seminyak Beach Resort And Spa. E-Jurnal Manajemen Unud, Vol 4 No.10

[15] Porter L. Wallach, 1983, Motivation and Work Behavior, Academic Press, New York.

[16] Rinawati, Agustina, 2013, Pengaruh Kepemimpinan Transformasionaldan Budaya Organisasi Terhadap Kepuasan kerja dan Kinerja karyawan PT. Jamsostek (Persero) Cabang Surabaya. Jurnal Ilmu Ekonomi \& Manajemen Vol.9 No.1

[17] Robbins, Stephen, P, 2006, Organizational Behavior : Concepts,Controversies, Applications, Prentice-Hall Internasional, Inc, Englewood Clifts, New Jersey.

[18] Salovey, Caruso and Mayer, 2002, The Positive psychology of emotional intelligence, Oxford University Press, New York.

[19] Schemerhorn, JR, Jr, 1991, Intercultural Management Training, An Interview with Asma Abdullah, Journal of Management Development, Vol.35, No.3 pp.47-64.

[20] Supriyanto, and Sani Achmad, Eka Afnan Troena, 2012, Pengaruh Kecerdasan Emosional dan Kecerdasan Spritual terhadap Kepemimpinan Transformasional, Kepuasan Kerja dan Kinerja Manajer (Studi pada Bank Syari'ah Kota Malang), Jurnal Aplikasi Manajemen, Vol.10 No.4

[21] Suryana, and Nana, Siti Haerani, Muhammad Indrus Taba, 2010, Pengaruh Kepemimpinan dan Motivasi Kerja Terhadap Kepuasan Kerja Kayawan dan Kinerja Perusahaan (Studi Kasus di Divisi Tambang PT. Inco Sorowako)

[22] Undang-Undang RI No.20 Tahun 2003 tentang Sistem Pendidikan Nasional

[23] Wallach, EJ, 1983, Individual Organization The Cuktural Match Training and Development, Journal, Vol. 12, pp 28-36.

\section{APPENDIX 1}

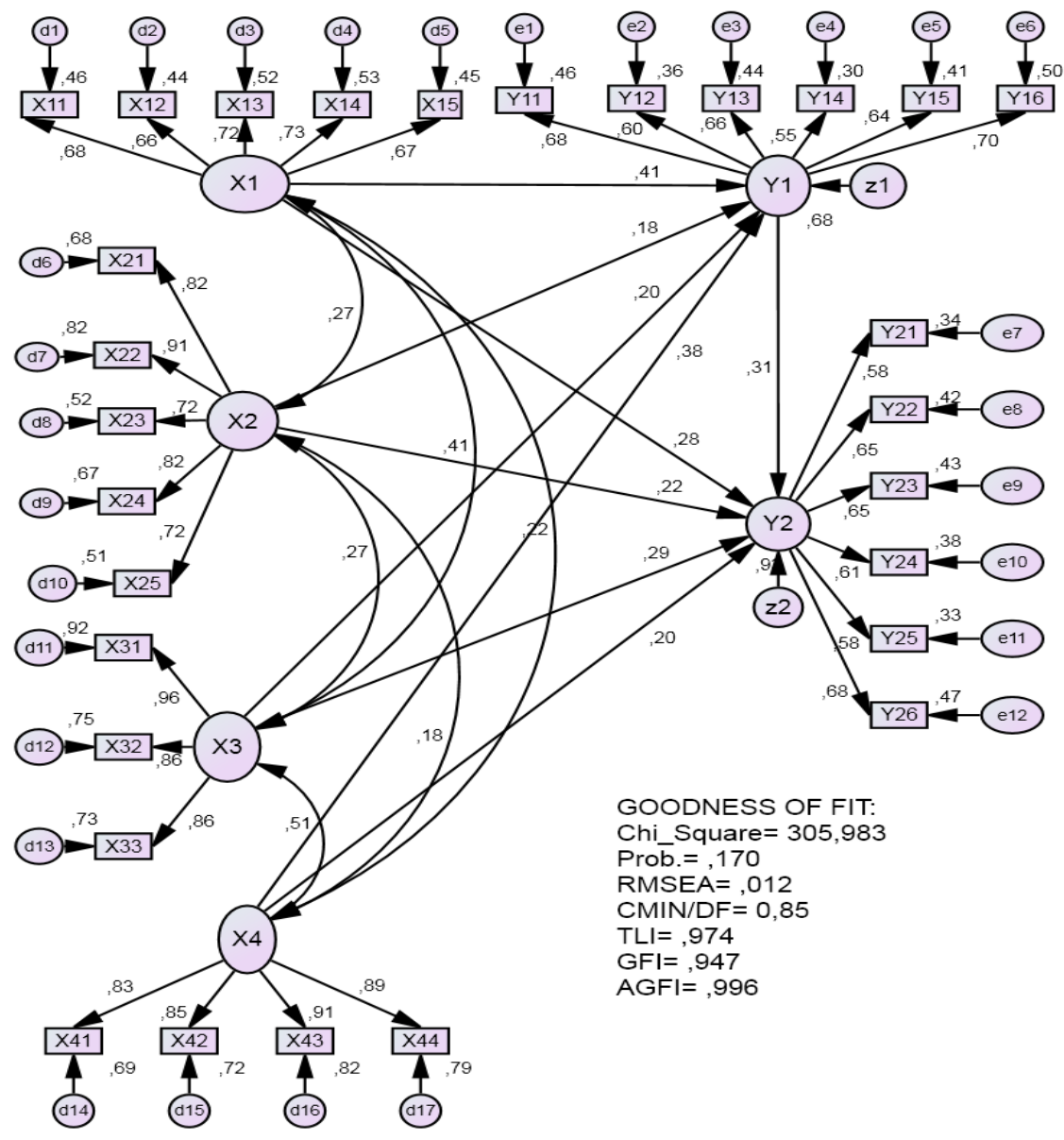

